\section{ROLE OF GREEN HRM: AN EIMPIRICAL STUDY IN THE COLLEGES OF COIMBATORE CITY}

KEY WORDS: Green Human Resource Management, management techniques

\title{
Dr.N.S.Lissy
}

Assistant Professor in Commerce, Department of B.Voc (Banking, Stock \& Insurance), PSG College of Arts and Science.

Recently there has been observed an increasing attentiveness within business communities on the significant of going green and adopting various environment management techniques. Today, Green Human Resource Management has become a key business strategy for the significant organizations where Human Resources Departments play a pivotal role in going green at the office. The Green Human Resource Management has emerged from companies engaging in practices related to protection of environment and maintaining ecological balance. The slogan is earning profit through environmental and maintains ecological balance. From the perspective of green human resource management, this study argues that Green HRM can play a useful role in business in promoting environmental related issues by adopting and following the processes.

\section{INTRODUCTION:}

The term 'GREEN HR' is often used to refer to the contribution of HR policies and practices towards the broader corporate environmental agenda of protection and preservation of natural resources. When we talk about Green HR, two essential elements have to be considered: environmentally friendly HR practices and the preservation of knowledge capital.

The impact of our daily activities on the environment and the desire to go green has expanded from just individuals to organizations. More organizations are volunteering to operate in a more environmentally responsible way.

The Green Human Resources Management is based on green movement related to Protection of Environment and save the planet Earth from future disasters caused by the organizations in order to achieve their sole objective of profit maximization. The Green Human Resource Management will play an important role in Industry to promote the environment related issues by adopting it, in management philosophy, HR policies and practices, training people and implementation of laws related to Environment Protection.

\section{Benefits of Green HR Initiatives}

Green HR initiatives help companies find alternative ways to cut cost without losing their top talent. Green HR refers to the contribution of people management policies and activities towards this broader agenda. It's an important issue for HR because it is clearly an important issue for all employees, as well as customers and other stakeholders. It's also one in which HR can have a big impact without causing much expenditure, good environmental management can improve sales and reduce costs, providing funding for green benefits to keep staff engaged.

\section{Scope of the Study:}

- Green HRM helps to develop Green learning environment in the organization.

- It develops a learning environment to educate HR on efficient Green practices to be utilized in their professional as well as personal lives.

\section{Objectives of the Study:}

- To understand the environmental related issues and reduce environmental problems, hazards and pollution in colleges.

- To explore constructs of green HRM in colleges.

- To identify how educational institutions, today develop human resource policies for promoting environment management initiatives.

\section{Review of Literature:}

Aravamudhan (2012) Green HRM involves addressing the company carbon footprint by cutting down on usage of papers, reducing unwanted travel. Green HRM is about the holistic application of the concept of sustainability to organization and its workforce. It has been found out in various researches that HR department in many companies are increasingly greening their processes to gain competitive advantage over others.

The study by Jabbar et al., (2012) identified the impact of human resources management on principles of environmental management implementation in company and identified the link to operational performance. The study adopted a primary empirical approach and identified that HRM practices including recruitment, feedback and compension were found to have an impact on environmental management practices of the company.

John R.Rathgeber (2007) has said in his research that many business leaders are embracing Corporate Sustainability and Green Business practices as a way to improve their operations and enhance their competitiveness.

Analysis and Interpretation:

Chi-Square Analysis

Age and Implement Environmental Initiatives:

\begin{tabular}{|l|c|c|c|}
\hline \multicolumn{4}{|c|}{ Chi-Square Tests } \\
\hline & Value & Df & $\begin{array}{c}\text { Asymptotic } \\
\text { Significance }\end{array}$ \\
\hline Pearson Chi-square & 17.968 & 6 & .006 \\
\hline Likelihood Ratio & 21.058 & 6 & .002 \\
\hline Linear-by-Linear Association & 9.420 & 1 & .002 \\
\hline N of Valid Cases & 100 & & \\
\hline \multicolumn{2}{|c|}{ 5 cells (41.7\%) expf<5. Min exp $=1.10 \ldots$} \\
\hline
\end{tabular}

Null Hypothesis (H0): There is no significant relationship between Age and Implement environmental initiatives.

\section{Inference:}

From the above table it is found that $\mathrm{x}^{2}=6, \mathrm{P}=.006$ is statistically significant at $5 \%$ level. Therefore, Null hypothesis is rejected at $5 \%$ level of significance. Hence, Alternative hypothesis is accepted and it can be concluded that there is association between Age and Implement environmental initiatives.

Age and Strength of the College:

\begin{tabular}{|l|c|c|c|}
\hline \multicolumn{4}{|c|}{ Chi-Square Tests } \\
\hline & Value & Df & $\begin{array}{c}\text { Asymptotic } \\
\text { Significance }\end{array}$ \\
\hline Pearson Chi-square & 12.885 & 6 & .045 \\
\hline Likelihood Ratio & 12.707 & 6 & .048 \\
\hline Linear-by-Linear Association & 5.598 & 1 & .018 \\
\hline N of Valid Cases & 100 & & \\
\hline \multicolumn{2}{|c|}{7 cells (58.3\%) expf<5. Min exp $=.22 \ldots$} \\
\hline
\end{tabular}


Null Hypothesis (H0): There is no significant relationship between Age and Strength of the College.

\section{Inference:}

From the above table it is found that $\mathrm{x}^{2}=6, \mathrm{P}=.045$ is statistically significant at $5 \%$ level. Therefore, Null hypothesis is rejected at $5 \%$ level of significance. Hence, Alternative hypothesis is accepted and it can be concluded that there is association between Age and Strength of the College.

Experience and Induction Programmers' Showing Green Citizenship Behavior:

\begin{tabular}{|l|c|c|c|}
\hline \multicolumn{4}{|c|}{ Chi-Square Tests } \\
\hline & Value & Df & $\begin{array}{c}\text { Asymptotic } \\
\text { Significance }\end{array}$ \\
\hline Pearson Chi-square & 41.817 & 12 & .000 \\
\hline Likelihood Ratio & 36.047 & 12 & .000 \\
\hline Linear-by-Linear Association & .555 & 1 & .456 \\
\hline N of Valid Cases & 100 & & \\
\hline \multicolumn{2}{|c|}{ 15 cells (75.0\%) expf<5. Min exp $=.60 \ldots$} \\
\hline
\end{tabular}

Null Hypothesis (H0): There is no significant relationship between Experience and Induction Programmers' Showing Green Citizenship Behavior.

From the above table it is found that $\mathrm{x}^{2}=12, \mathrm{P}=.000$ is statistically significant at $5 \%$ level. Therefore, Null hypothesis is rejected at $5 \%$ level of significance. Hence, Alternative hypothesis is accepted and it can be concluded that there is significant relationship between Experience and Induction Programmers' Showing Green Citizenship Behavior.

\section{Findings:}

- It is clear that $70 \&$ of respondents agree to develop induction programmers' showing Green citizenship behavior of employees.

- It is clear that $59 \%$ of respondents agree that Green HRM reduces stress amoung employees.

- It is clear that $55 \%$ of respondents agree to encouraging creativity to have best environmental issues.

- It is found that $70 \%$ of the respondents agree that employees are encouraged to engage in green interpersonal citizen behavior of the college.

- It is clear that majority of the respondents $75 \%$ strongly agree that green HRM practice and functions in colleges pave way for sustained development.

\section{Suggestions:}

From the study, the researcher finds that there are some of the areas where the management shall focus on, in order to strength the Green HRM practices and policies in the colleges.

- Management shall take immediate effective steps to ban usage of plastic inside the college campus.

- Awareness programmes like street play, slogan, kavithai like the same shall be arranged on that teaching, nonteaching, students and other stakeholders any withdraw the usage of plastic inside the college campus.

- The management shall motive the staff and students who are actively involved in green human resources management activities either in the form of monetary incentives or non-monetary incentives.

- The office of controller of examinations shall introduce easpects innovative practices in registration, sending of applications, payment of fees downloading of Hall tickets, Mark statement so that the volume of paper work may be reduced.

\section{CONCLUSION:}

The employees and practitioners can establish the usefulness of linking employees involvement and participation in environment management programs to improve organizational environmental performance, like with a specific focus on waste management recycling, creating green products.
Employees can help employers to adopt Green HRM policies and practices. IT Professionals are the representatives of global economy. The nature of their work involves high level autonomy and they will show a strong commitment to their jobs. In current scenario, most of the employees now realize the value sustainability has on their competitiveness, reputation and ability to attract and retain top talent.

\section{REFERENCES:}

1. Performance appraisal and management: Concepts, antecedents and implications.

2. Sustainable HRM and Green HRM: The Role of Green HRM in Influencing Employee Pro-environmental Behavior at Work. J Sustain Res. 2020;2(3): e200026.https://doi.org/10.20900/jsr20200026 